Eskişehir Osmangazi Üniversitesi iißBF Dergisi

Aralık 2020, C. 15, S. 3, $939-958$

Başvuru : 21.08.2019

Kabul : :01.04.2020

\title{
Türkiye'de Vergi İdaresinin Tahsil Yetkisini Kullanımında Sınırların Aşılmasından Kaynaklanan Sorunlar ${ }^{1}$
}

\author{
Betül Hayrullahoğlu²
}

\begin{abstract}
Türkiye'de Vergi İdaresinin Tahsil Yetkisini Kullanımında Sınırların Aşılmasından Kaynaklanan Sorunlar

Öz

Devletin sahip olduğu en önemli yetkilerden biri vergilendirme yetkisidir. Bu yetkinin etkili kullanımı için vergi idaresi tahsil yetkisi ile donatılmıştır. Bu çalışmada tahsil yetkisinin sınırları ve sınırların aşıımasının sonuçları üzerinde durulmuştur. Sınırların ve sonuçların belirlenmesinde doküman analizi yönteminden yararlanılmıştır. Çalışmanın sonuçlarına göre sınırların aşılmasının mükellefler, vergi idaresi ve yargı organları üzerinde hukuki, mali ve ekonomik çok sayıda negatif etkileri bulunduğu saptanmıştır. Bu sonuçlar yetkinin kullanımında sınırlara uyulmasının öneminin daha da anlaşılmasını sağlamıştır.
\end{abstract}

Anahtar Kelimeler: Tahsil Yetkisi, Cebren Tahsil, Mükellef Hakları
Problems Due to Exceeding the Boundaries of Using Tax Collecting Power of Tax Administration in Turkey

Abstract

One of the most important powers of the government is the taxation power. For the effective use of this power, the tax administration is equipped with the tax collecting power. This study focused on the boundaries of the tax collecting power and the consequences of exceeding the boundaries. Document analysis method was used to determine the boundaries and results. According to the results of the study, exceeding the boundaries has many legal, financial and economic negative effects on taxpayers, tax administration and judicial bodies. These results allowed a better understanding of the importance of complying with the boundaries in the exercise of power.

Keywords: Tax Collecting Power, Enforced Collection, Taxpayer Rights

\section{Giriş}

Kamu gelirlerinin belirlenen zamanlarda ve etkin bir şekilde tahsili, kamu hizmetlerinin sunumu için yapılacak olan kamu harcamalarının finansmanı açısından önem taşımaktadır. Bu noktada devlet, kamu alacağının mükellef tarafından gönüllü olarak ödenmemesi durumunda alacağını tahsil etmesi bakımından özel bir yetki ile donatılmıştır. İdarenin yükümlülüğünü kendiliğinden yerine getirmeyen kişiden alacağını zorla alabilmesi noktasında sahip olduğu güç tahsil yetkisi olarak ifade edilmektedir.

Tahsil yetkisinin dayanağını, 6183 sayılı Amme Alacaklarının Tahsil Usulü Hakkında Kanun (AATUHK) oluşturmaktadır. Bu yetkinin kullanımı kapsamında idare, kamu alacaklarını herhangi bir mahkeme kararına ya da icra ve iflas dairelerinin yardımına gerek duymaksızın kendi teşkilatı ile haciz ve satış gibi yollara başvurmak suretiyle tahsil edebilmektedir. Ancak hiçbir yetki sınırsız olmadığı gibi, bu yetki de sınırsız değildir. Özellikle vergilerin başta mülkiyet hakkı olmak üzere anayasal haklara müdahale niteliği göz önünde bulundurulduğunda bu yetkinin hukuk devleti ilkesi çerçevesinde ve anayasal sınırlar dâhilinde kullanılması gereği kendiliğinden ortaya çıkmaktadır. Yine tüm idari işlemler gibi tahsil yetkisinin kullanımı sürecinde yapılan işlemlerin de, yetkili idarece, belirlenen şekil ve usul kurallarına uygun olarak, kanunların öngördügü hukuki nedenlere dayanarak, kamu yararı amacıyla yapılmaları gerekmektedir. Ayrıca bazı durumlarda

\footnotetext{
${ }^{1}$ Bu çalışma Dokuz Eylül Üniversitesi Sosyal Bilimler Enstitüsü Maliye Anabilim Dalı’nda Prof. Dr. Zeynep Arıkan danışmanlığında Betül Hayrullahoğlu tarafından "Türkiye'de Vergi İdaresinin Tahsil Yetkisi ve Sınırları" ismiyle tamamlanarak 21.02.2018 tarihinde savunulan doktora tezinden türetilmiştir.

${ }^{2}$ Arş. Gör. Dr., Uşak Üniversitesi iiBF, Maliye Bölümü. betul.hayrullahoglu@usak.edu.tr, Yazar ORCID bilgisi: http://orcid.org/0000-0001-6881-8093
} 
kamu alacağının tahsilinin ertelenmesi ve sona ermesine bağlı olarak idarenin tahsil yetkisinin kullanımı da ertelenmekte ya da sona ermektedir. Bu bakımdan idare tahsil yetkisinin kullanımında tüm bu sınırlara bağlı olarak işlem yapabilmektedir.

Çalışmada idarenin tahsil yetkisini kullanımında sınırları aşmasının ne gibi sorunlara yol açtığı sorusundan yola çıkılmakta ve sonuçlar mükellefler, vergi idaresi ve yargı organları açısından ele alınmaktadır.

\section{Tahsil Yetkisi ve Sınırları}

Çalışmanın bu bölümünde öncelikle tahsil yetkisi kavramı açıklanmakta, sonrasında ise bu yetkinin kullanımına ilişkin sınırlar; anayasal ilkeler, idari işlemler ve yetkinin kullanımı ya da sona ermesine ilişkin durumlar açısından ele alınmaktadır.

\subsection{Tahsil Yetkisi Kavramı}

Kamu alacaklarının kamu hizmetlerinin devamı için bir takvim yılı içerisinde tahsilinin zorunlu olması, bu hizmetlerin finansmanı için gerekli olan kamu gelirlerinin tehlikeye atılmadan belirlenen süreler içinde ve kısa zamanda tahsilini zorunlu kılmaktadır. Bu nedenle kamu alacaklarının takip ve tahsilinde, genel takip sisteminden ayrı ve daha kolay, hızlı ve etkili usuller öngören bir takip sisteminin varlığına ihtiyaç duyulmaktadır (Öner, 2017: 184). İdare, kendisine bu ayrıcalıklı takip sisteminden yararlanma yetkisi veren tahsil yetkisine sahip olması sayesinde, mahkemeye ya da icra ve iflas dairelerinin yardımına gerek duymaksızın ve İcra ve iflas Kanunu'ndaki hükümlere bağlı kalmaksızın kamu alacağını kendisi tahsil edebilmektedir (Onar, 1966: 1645).

Alacaklı idarenin tahsil dairesi olarak alacağını doğrudan harekete geçme ve zor kullanma yoluyla tahsil etme imkânı, idarenin haiz olduğu resen icra yetkisinin kamu alacaklarının zorla tahsili alanına yansıması olan tahsil yetkisinden doğmaktadır. Diğer bir ifadeyle tahsil yetkisi, idarenin resen icra yetkisinin kamu icra hukukundaki yansımasını oluşturmaktadır (Bayraklı, 2009: 269).

Tahsil yetkisi; "idarenin kamu hukuku alanındaki alacaklarını, İcra ve iflas Kanununda (iiK) düzenlenen usullere uymak zorunda olmaksızın ve icra ve iflas dairelerinin yardımına gerek duymaksızın, kendi teşkilatı ile ve haciz ve satış gibi cebri yollara başvurmak suretiyle tahsil etme yetkisine sahip olması" olarak tanımlanmaktadır (Günday, 2017: 244). Başka bir deyişle tahsil yöntemlerinin özelliği; "mahkeme kararına ya da cebri icra ile görevlendirilmiş icra dairelerinin aracılığına gerek duymaksızın idarenin alacağının kendi tahsil dairesince tahsil edilmesidir" (Karahanoğulları, 2012: 318).

Tahsil yetkisi 21.07.1953 tarih ve 6183 sayılı Kanunda düzenlenmiştir. Kamu alacağı vadesinde ödenmemesi durumunda bu kanun hükümlerine göre zorla tahsil edilmektedir (Giritli vd., 2006: 890). Her ne kadar 6183 sayılı Kanun devletin çıkarlarını korumayı amaçlasa da, aynı zamanda idarenin keyfi hareketlerinin önüne geçilmesi ve bireylerin korunmasına yönelik olarak vergi ilişkisinin tahsil aşamasını kurallara bağlamakta ve kamu alacaklarının tahsilinin güvence altına alınmasını sağlamaktadır (Savaş, 2001).

\subsection{Tahsil Yetkisinin Kullanımında Sınırlar}

İdarenin sahip olduğu tahsil yetkisinin hukuka uygun kullanıldığından söz edebilmek için kanuni düzenlemeler ve anayasal sınırlar dâhilinde hareket etmesi gerekmektedir. Zira vergiler kişilerin başta mülkiyet hakkı olmak üzere birtakım anayasal haklarına müdahale edilmesi anla- 
mına gelmektedir. Vergi kanunlarının bu hak ve özgürlükleri aşırı ve ölçüsüz bir şekilde sınırlandırması kişilerin anayasal güvencelerden mahrum bırakılması anlamına gelecektir (Töralp, 2012: 163). Bu bakımdan her yetkide olduğu gibi vergi idaresinin tahsil yetkisinde de bazı sınırlar bulunmakta ve bu sınırların aşııması hukuka aykırılıklara yol açmaktadır.

\subsubsection{Anayasal ilkelere iliş̧kin Sınırlar}

Bir yetkinin sınırları, o yetkinin hangi ilke ve kurallara bağlı olarak kullanılacağını belirtmektedir (Üstün, 2007: 40). Anayasa, idarenin tahsil yetkisinin kaynağını oluşturan 6183 sayılı Kanun'un sınırını oluşturmaktadır (Gözübüyük ve Tan, 2011: 698). Bu bakımdan idare, tahsil yetkisini kullanırken anayasal ilkelere bağlı kalmak durumundadır. Diğer bir ifadeyle anayasal ilkeler idarenin tahsil yetkisinin sınırını oluşturmaktadır.

Idare her şeyden önce faaliyetlerinde Anayasa ve kanunlara uygun davranmak zorundadır. Bu durum hukuk devleti ilkesinin bir gereği olarak ortaya çıkmaktadır. Ancak bir devletin hukuk devleti olarak nitelendirilebilmesi için salt hukuk kurallarının konulmuş olması yeterli olmayıp, bu kuralların bireylerin hukuki güvenliklerini sağlaması şartı da aranmaktadır (Taylar, 2007: 199).

Anayasada öngörülen temel hak ve özgürlüklerin kullanılmasının ve insan haklarının yaşama egemen kılınmasının önkoşulu olan hukuki güvenlik ilkesi (Batun, 2010: 262), hukuk devletinin temel ilkelerinden bir tanesini oluşturmaktadır (Tavşancı, 2005: 140). Anayasa Mahkemesi bir kararında hukuk devletini "... insan haklarına saygı gösteren ve bu hakları koruyucu, âdil bir hukuk düzeni kuran ve bunu devam ettirmeye kendini zorunlu sayan ve bütün faaliyetlerinde hukuka ve Anayasa'ya uyan bir devlet... "olarak tanımlamıştır (Anayasa Mahkemesi, 11.10.1963 tarih, E. 1963/124, K. 1963/243).

Hukuk devleti ilkesi kapsamında idarenin tahsil yetkisini kullanımında korunması gereken temel hak ve hürriyetler başlıca; insan onuru, kişiliğin ve kişi özgürlüklerinin korunması, özel hayatın ve haberleşme özgürlüğünün korunması, mülkiyet hakkı ve çalışma hakkı gibi hak ve hürriyetlerden oluşmaktadır.

İdarenin tahsil yetkisinin bir diğer sınırını kanunilik ilkesi oluşturmaktadır. Vergilerin kanuniliği ilkesi vergi ve benzeri mali yükümlülüklerin kanunla konulup, değiştirilip, kaldırılmasını ifade etmektedir. Vergi hukukunda vergilerin kanuniliği ilkesinin bir sonucu olarak kanuni idare ilkesi önem kazanmaktadır (Çağan, 1980: 137). Zira vergilere ilişkin esaslı unsurların kanunla konuluyor olmalarının ötesinde idarenin vergilendirmeye ilişkin tarh ve tahsil işlemlerinin de kanunlara uygun surette yapılması gerekmektedir (Kumrulu, 1979: 150-151). Bu kapsamda idarenin tahsil yetkisinin kullanım alanı olan cebri icra alanında kanunilik ilkesi ve kanuni idare ilkesi en temel ilkeler konumundadır. Kanunilik ilkesi gereği tahsil yetkisinin kullanımına ilişkin yorum ve uygulamaların kanunun sınırlarını aşmama zorunluluğu bulunmaktadır (Özekes, 2009: 89-90).

Kişilerin temel hak ve hürriyetlerine ağır müdahale gerektiren idarenin tahsil yetkisinin kullanımı işlemlerinde ölçülülük kriteri de önem kazanmaktadır (Azrak, 2010: 102). Kamu alacağının tahsilinde görevli haciz memurlarının borçlunun temel haklarına müdahale niteliğini taşıyan haciz işlemini uygulaması esnasında ölçülülük ilkesine uymaları gerekmektedir (Karakoç, 2013: 1283). Cebri icra uygulamalarında ölçülülük ilkesinin alt ilkeleri olan elverişlilik ve gereklilik noktasında genellikle fazla bir sorunla karşılaşılmazken, amaç ve araç arasındaki orantının sağlanması her zaman mümkün olamamaktadır. Bu sebeple cebri icra alanında ölçülülük ilkesi orantılılık şeklinde de ifade edilmektedir (Özekes, 2009: 209-210). 
Son anayasal ilke olarak sosyal devlet ilkesi önem kazanmaktadır. Zira devletin sırf alacağını tahsil etmek uğruna borçlunun her şeyini elinden alarak yardıma muhtaç hale getirmesi devletin sosyal koruma görevi gereği ona asgari hayat standartlarını sağlamasını zorunlu kılacaktır. Diğer bir ifadeyle devlet bir eliyle aldığını, diğer eliyle borçluya vermek zorunda kalacaktır. Bu bakımdan her ne kadar icra hukuku yaptırım ve zor kullanma hukuku olsa da bir cezalandırma hukuku olmadığı unutulmamalı (Özekes, 2009: 222-223) ve yetkinin borçlunun asgari hayat sınırlarına zarar vermeyecek sınırlar dahilinde kullanııması sağlanmalıdır.

\subsection{2. İdari İşlemlere İlişkin Sınırlar}

Tüm idari işlemler gibi tahsil yetkisinin kullanımı sürecinde yapılan işlemler de, yetkili idare tarafından, belirlenen şekil ve usul kurallarına uygun olarak, kanunların öngördüğü hukuki nedenlere dayanarak ve kamu yararı amacıyla yapılmaktadırlar (Gözübüyük ve Tan, 2011: 699700). Bu bakımdan vergi idaresi tahsil yetkisinin kullanımında kanunun idari işlemlere ilişkin olarak öngördüğü sınırlara bağlı kalmak zorundadır. Bu sınırlar idari işlemlere ilişkin yetki, şekil, sebep, konu ve amaç unsurlarına ilişkin sınırlardır.

Kural olarak kamu alacaklarının vadesinde ödenmemesi nedeniyle yapılacak takip, vergiyi tarh ve tahakkuk ettiren ilgili vergi dairesince, yani mükellefin bağlı olduğu vergi dairesince tahsil dairesi sıfatıyla yapılmaktadır (Karakoç, 2016: 104). Bu bakımdan vergi dairelerinin tahsil yetkilerini kullanırken kanunun öngördüğü yetkiyi haiz olup olmadıklarını araştırmaları gerekmektedir.

İdarenin bir işlemi yapabilmesi için "yetkili" olması yeterli olmayıp, ayrıca o işlemi yapmak için "sebebi" de bulunması gerekmektedir (Arslaner, 2010: 192). İdarenin tahsil yetkisinin kullanımı sürecinde yapmış olduğu işlemlerin sebebi 6183 sayılı Kanun'un 54'üncü maddesi hükmüne göre kamu alacağının vadesinde ödenmemiş olmasıdır. Ancak kamu borcunun vadesinde ödenmemesi durumunun kanunda öngörülen gerekçelere bağı olarak gerçekleşmesi durumunda idare bu yetkisini olayın niteliğine bağlı olarak geçici bir süreyle ya da tamamen kullanamayacaktır.

Tahsil yetkisinin kullanımında şekli kurallara uyulması da önem arz etmektedir. Zira idari işlemi gerçekleştirecek olan kamu görevlisinin işlemin sonuçlarına ilişkin daha doğru düşünmesini ve tedbirli davranmasını sağlamak ve idari işleme muhatap olanların hukuki güvenliklerini tesis edebilmek adına idari işlemlerin belirli şekil kurallarına uyularak ve belirli usuller izlenmek suretiyle yapılması gerekli bulunmuştur (Ağar, 2009: 158). Bu bakımdan şekil kuralları idare için bir düzen ve kolaylık sağlarken, idare edilenler açısından ise bir güvence anlamına gelmektedir (Üstün, 2007: 36).

İdari işlemlere ilişkin diğer bir unsur konu unsurudur. Kamu alacağının tahsili için yetkili tahsil dairesinin kamu alacağı niteliği taşımayan bir alacak için takip ve tahsil işlemlerine girişmesi, işlemi konu unsuru açısından hukuka aykırı kılmaktadır (Ağar, 2009: 160). Bu bakımdan yetkili vergi idaresinin, kamu alacağı niteliği taşımayan bir alacak için tahsil yetkisini kullanması söz konusu olamamaktadır.

Kanunda açıkça gösterilmiş olsa da olmasa da her idari işlemin genel amacı kamuya yarar sağlamaktır. Devlet yetkisi devlet aracılı̆ıyla topluma ait olduğundan, hiçbir devlet yetkisinin kamu yararından başka özel bir amaç için kullanılması mümkün olamayacaktır (Arslaner, 2010: 194). İdarenin tüm eylem ve işlemlerinde olduğu gibi zor alım işlemlerinde de amaç kamu yararının sağlanmasıdır. Tahsil yetkisinin kullanımı sürecinde vergi idaresi, kamu alacağının Hazine'ye biran önce intikalini ve vergi sisteminde adaleti sağlayarak kamu yararının sağlanmasını 
amaçlamaktadır. Bu bakımdan vergi idaresinin tahsil yetkisinin kullanımı kamu yararı amacıyla sınırlı olup, yetkinin özel bir amaçla kullanımı, yapılan işlemi amaç unsuru bakımından geçersiz kılmaktadır.

\subsubsection{Tahsil Yetkisinin Kullanımının Ertelenmesi ve Sona Ermesine Ilişkin Sınırlar}

Vergi idaresinin tahsil yetkisini kullanımı sürecinde kamu alacaklarının tahsili, idari işlemler ya da kendiliğinden ortaya çıkan durumlara bağlı olarak bir süre ertelenebilmekte ya da sona erebilmektedir (Ağar, 2009: 297). Bu durumlar nedeniyle vergi idaresinin tahsil yetkisini kullanımı geçici olarak ya da tamamen sınırlanmaktadır.

İarenin tahsil yetkisini erteleyen hususlardan ilki tehir yani tahsilatın geri bırakılması uygulamasıdır. Vergi idaresi takibatın geri bırakıldığı bu süreler boyunca tahsil yetkisini kullanamamaktadır. Tahsilatın geri bırakılması; yürütmenin durdurulması, aciz hali ve ölüm durumlarında söz konusu olmaktadır.

Hakkında yürütmenin durdurulması kararı verilen bir kamu alacağı nedeniyle ödeme emri tebliğ edilmesi ve zor alım işlemlerine girişilmesi mümkün olamamaktadır. Geçici olarak tahsil edilebilirliğini yitiren alacak, ancak dava sonucunda verilen karara göre yeniden talep edilebilir hale gelmektedir (Karakoç, 2000: 137). Aciz halinde de tahsil yetkisinin kullanımı, zamanaşımı süresi ile sınırlı olmak üzere geri bırakılmaktadır (Gerçek, 2011: 100). Aciz hali 6183 sayılı Kanun'un 75'inci maddesinde; "yapılan takip sonunda, borçlunun haczi caiz malı olmadığı veya bulunan malların satış bedeli borcunu karşılamadığı takdirde borçlu aciz halinde sayılır" denilmek suretiyle tanımlanmıştır.

6183 sayılı Kanun'un 50'nci maddesinde ise sosyal ve insani düşüncelerle, ölüm halinde takibin geri bırakılması düzenlenmiş bulunmaktadır. Ölüm olayının gerçekleşmesi, kamu alacağının tahsilatının farklı şekillerde geri bırakılmasına neden olmaktadır (Gerçek, 2011: 100, 102). 6183 sayılı Kanun'un 50'nci maddesinde borçlunun ölümü halinde terekenin borçlarından dolayı ölüm günü ile beraber takibin 3 gün için geri bırakılacağına hükmedilmiştir. Bu durumda terekenin borcunun takibine 3'üncü günün bitiminden itibaren devam edilmektedir. Yine aynı maddenin ilk bendinde ise kamu borçlusunun bazı yakınlarının ölümü halinde tahsilatın ölüm günü ile beraber 3 gün için geri bırakılacağına hükmedilmiştir. Maddede geçen mükellefin bazı yakınları kavramına; borçlunun karısı, kocası, kan veya sıhriyet itibariyle usul veya füruundan birisi girmektedir. 6183 sayılı Kanun'un 50'nci maddesinde yapılan düzenleme gereğince, mirası ret süresi olarak tanınan 3 ay süresince mirasçılar henüz mirası kabul ya da reddetmemişlerse Medeni Kanunda belirtilen 3 aylık süre sona erene dek takip geri bırakılmaktadır.

İdarenin tahsil yetkisini erteleyen diğer durumlar tecil ve mücbir sebep durumlarıdır. Bir kamu borcunun vadesinde ödenmesi ya da haciz tatbik edilmesi veya haczedilen malların paraya çevrilmesi kamu borçlusunu çok zor duruma düşürecekse, kamu alacağı borçlu tarafından yazı ile istenmiş ve teminat gösterilmiş olmak şartıyla, alacaklı kamu idaresince veya yetkili kılacağı makamlarca; 36 ayı geçmemek üzere ve faiz alınarak tecil olunabilmektedir. Tecil edilen kamu alacağı için idare bu süre boyunca tahsil yetkisini kullanamamaktadır.

Mücbir sebepler ise; genel olarak kişilerin iradesi dışında ortaya çıkan, öngörülemeyen veya öngörülse bile her türlü imkân ve araca rağmen önlenemeyen olaylar olarak tanımlanmaktadır (Kızılot vd., 2008: 178). Mücbir sebebin tahsilat aşamasında ortaya çıkması durumunda bu sebep ortadan kalkıncaya kadar idare tahsil yetkisini kullanamamakta ve gecikme zammı da uygulanmamaktadır (Gerçek, 2011: 75). 
Vergi kanunlarında yer alan bazı durumların gerçekleşmesi ile birlikte vergi idaresinin tahsil yetkisi sona ermekte ve kullanılamamaktadır. Vergi idaresinin tahsil yetkisinin kullanımının en doğal sona erme yolu ödemedir. Zira tahsil yetkisinin kullanımı ile asıl amaçlanan kamu alacağının tahsili, bu yolla sağlanmış olmaktadır. Ayrıca ölüm ve fesih, terkin, zamanaşımı, af ve takas durumlarında da vergi idaresinin tahsil yetkisinin sona ermesi söz konusu olmaktadır.

\section{Sınırların Aşılmasının Sonuçları}

Tahsil yetkisinin kullanımı sürecinde ödeme emri düzenlenmesi ve tebliği, teminatın paraya çevrilmesi, şahsi kefilin takibi, haciz uygulanması ve satış işleminin gerçekleştirilmesi aşamalarında sınırlar aşılmak suretiyle bir takım hukuka aykırılıklar yapılabilmektedir. İdare tarafından yapılan bu hukuka aykırılıklar bizzat idarenin kendisi açısından olumsuz sonuçlara yol açtığı gibi mükellefleri de olumsuz yönde etkilemektedir. Vergi ilişkisinin borçlu ve alacaklı ayağını oluşturan bu kişiler arasında çıkan uyuşmazlıkların yargıya taşınması nedeniyle de vergi yargısının iş yükü artmaktadır.

Çalışmanın bu bölümünde vergi idaresinin tahsil yetkisini kullanımında sınırların aşılmasının sonuçları mükellef, idare ve vergi yargısı açısından açıklanmaktadır.

\subsection{Mükellefler Açısından Sonuçlar}

Roma Hukuku'nun temel bilgi kaynağı olan Corpus luris Civilis'in bölümlerinden biri olan (Emiroğlu, 2002: 86) Digesta'da da belirtilmiş olduğu gibi "bütün hukuk insan için konmuştur" (Ökçesiz, 1998: 35). Bu bakımdan konulan hukuk kurallarının insanlara zarar vermeyecek şekilde gereği gibi uygulanması önem taşımaktadır.

Türkiye'de kamu gelirlerinin büyük bir kısmını vergiler oluşturduğundan, bireyler devletin kamu gelirleri kısmı ile çok yakın bir ilişki içerisinde bulunmaktadır (Korkusuz, 1998: 292). Vergiler kişilerin başta mülkiyet hakkı olmak üzere birtakım anayasal haklarına müdahale edilmesi anlamına gelmekte olup, vergi kanunlarının bu hak ve özgürlükleri ölçüsüz ve aşırı olarak sınırlandırması kişilerin anayasal güvencelerden mahrum edilmesi anlamına gelebilmektedir (Töralp, 2012: 163). Bu noktada hukuk devleti ilkesi, vergi hukuku açısından bir sınır olma niteliği taşımaktadır. Zira hukuk devletinde vergilendirme yetkisinin yasama ve yürütme organları tarafından keyfi olarak kullanılmasının önüne geçilmesine çalışılmaktadır (Öncel vd., 2011: 39).

T.C. Anayasasının 2'nci maddesinde güvence altına alınan hukuk devletinin bir gereği olarak kişilerin anayasal haklarının korunması için bireylerin yanı sıra idarenin de eylem ve işlemlerinde kanunlara uygun davranması zorunluluğu ortaya çıkmaktadır. Bu bağlamda hukuk devleti ilkesi devlete eylemlerinde yasaklayıcı bir alan çizerken, bireylere de çizilen sınırların aşılmayacağına dair güvence sağlamaktadır (Bayraklı ve Odabaş, 2000: 147). Bu sebeple idarenin tahsil yetkisini kullanımında kanunlara aykırı hareket etmesi kanuni idare ilkesine aykırılık oluşturarak temel hak ve özgürlüklerin zarar görmesi sonucunu doğurmaktadır.

Idarenin tahsil yetkisini kullanımı sürecinde yapmış olduğu hukuka aykırı işlemler nedeniyle bireylerin mülkiyet haklarının yanı sıra; insan onuru, kişiliğin ve kişi özgürlüklerinin korunması, özel hayatın ve haberleşme özgürlüğünün korunması, hak arama özgürlüğü, ailenin korunması ve çalışma hakkı gibi hakları da zarar görebilmektedir.

Anayasalarla güvence altına alınan tüm temel hakların amacı, insanın insan olarak onurlu bir hayat yaşamasını sağlamaktır. Bu bakımdan tahsil yetkisinin kullanımı sürecinde gerçekleştirilen hukuka aykırılıklarla temel hak ve özgürlüklerin zarar görmesi her şeyden önce insan onuruna zarar vermektedir. İdarenin tahsil yetkisini kullanımında keyfiliğe vardığı noktada insan onuru zedelenmeye başlamaktadır (Özekes, 2009: 110, 114). Bu sebeple vergi idaresinin gece vakti 
haciz uygulaması, haczedilemeyecek malları haczetmesi ya da kısmen haczedilmesine izin verilen gelirlerde kanunun belirlediği sınırları aşması, borçlunun tecil taleplerinin dinlenilmemesi veya yakınlarının ölümü halinde tahsilata üç günlük süre dolmadan devam edilmesi gibi uygulamaları neticesinde borçluların onurları, kişinin dokunulmazlığı, maddi ve manevi varlığı ile kişi özgürlüğü ve güvenliği gibi anayasal hakları zarar görmektedir. Benzer şekilde vergi idaresinin bu uygulamaları borçluların mesleki ve ticari faaliyetlerine zarar vererek çalışma haklarının gaspına ve ailelerinin geçimini sağlayamayacak duruma düşerek yardıma muhtaç hale gelmelerine yol açabilmektedir. Böyle bir durumum sosyal devlet anlayışı ile de çeliştiği açıktır.

Vergi idaresinin tahsil yetkisini kullanımı sürecinde yapmış olduğu hukuka aykırı işlemlerin borçlular tarafından yargıya taşınması doğaldır. Ancak borçlu ile idare arasında oluşan anlaşmazlıkların yargısal çözümünde kanunlarda devlet lehine ve borçlu aleyhine olacak şekilde yer alan bazı düzenlemeler borçluların uyuşmazlığı yargıya taşımaya endişe etmelerine ve dolayısıyla hak arama hürriyetlerine zarar verebilmektedir.

Ödeme emrine karşı açılan davalarda 6183 sayılı Kanun'un 51'inci maddesi uyarınca gecikme zammı uygulanan kamu alacaklarında dava boyunca zam işlemeye devam etmektedir (Alpaslan N. G., 2017). Borçlu tarafından davanın kazanılması halinde ilgili borç veya ceza yargı kararı ile terkin edilmiş olmakta, kaybedilmesi durumunda ise ilgili borcun aslı, cezalar ve gecikme zammı ile birlikte 6183 sayılı Kanun'un 58'inci maddesi uyarınca \% 10 oranında haksız çıkma zammıyla birlikte tahsil edilmektedir (Tosuner ve Arıkan, 2011: 146). Her ne kadar haksız çıkma zammı kötü niyetli itirazların önüne geçilmesi amacını taşıyor olsa da, ödeme gücü olmayan yükümlüler ve çok yüksek meblağlara itirazlarda taşıdığı risk bakımından borçluların dava açma hakkını kısıtlayarak (Kumrulu, 1981: 666) hak arama hürriyetlerine zarar vermektedir (Töralp, 2012: 180). Yine menfaati zarar gören mükelleflerin yargılamanın 2-3 yıl süreceği bir ortamda vergi idaresinin mükellefe karşı adeta "vergi terörü" uygulamayacağının bir garantisi olmaması (Gerçek, 2010: 39-40) nedeniyle de tam yargı davası açmaktan kaçınmaları da bu kişilerin hak arama hürriyetlerine zarar verebilmektedir.

Vergiler doğrudan mülkiyete yönelik bir müdahale olduğundan özünde tüm haksız müdahale ve düzenlemeler mükelleflerin mülkiyet haklarına zarar veriyor olmakla birlikte, bu süreçte mükelleflere yargı kararına göre iade edilecek vergilere faiz ödenip ödenmeyeceğine yönelik net bir düzenlemenin mevzuatta yer almamasının ayrıca ele alınmasının önemli olduğu düşünülmektedir. Yargı kararına göre iade edilecek vergilere faiz işletilip işletilemeyeceği ve işletilecek olması durumunda faiz oranının kanuni dayanağı konusunda bugüne dek vergi yargısında çeşitli görüşler ortaya atılmış ve tam bir uzlaşıya varılamamıştır. Bu durumda mükelleflerin zor alım işlemlerindeki hukuka aykırııklar nedeniyle yargıya başvurarak haklı çıkmaları halinde dahi enflasyonun aşındırıcı etkisine bağlı olarak oluşan zararlarının telafi edilmemesi nedeniyle mülkiyet hakları zarar görmektedir. Anayasa Mahkemesi, 2011 yılında almış olduğu kararında (Anayasa Mahkemesi, 10.02.2011 tarih, E. 2008/58, K. 2011/37);

Faiz, ekonomik açıdan paranın fiyatıdır... Gerek kişi gerek devlet yönünden, alacağının zamanında ödenmemesi halinde, ekonomik varlıkta enflasyon sebebiyle azalma olmakta, bir nevi mülkiyet hakkı zarara uğramakta... Hal böyle olunca da; mükellefe aylar-yıllar sonra iade edilen vergiye faiz işletilmemesi veya vade tarihinden sonraki dönemlerde işletilmesi kişi aleyhine mülkiyet hakkının ihlali sonucunu doğurmaktadır.

demek suretiyle faizin önemini belirtmiştir. Danıştay da bu karara atıf yaparak (D. 4. D., 06.10.2011 tarih, E. 2011/5499, K. 2011/6892); 
Faiz, Anayasa Mahkemesinin kararında da belirtildiği gibi, ekonomik açıdan paranın fiyatıdır. Herhangi bir kişinin kendisine ait olmayan parayı belirli süre kullanması, asıl para sahibinin bu ekonomik değerden mahrum bırakılması sonucunu doğuracağı gibi, enflasyona maruz kalan ekonomilerde, paranın değerini, yani alım gücünü enflasyon oranında yitirmesine de neden olacağından, parası uhdesi dışında kalan ve mülkiyet hakkı ihlal edilen bu kişiye haksız kullanım karşılığında faiz ödenmesi gerekmektedir,

demek suretiyle bu görüşü benimsemiştir.

Bilindiği gibi Vergi Usul Kanununun (VUK) 112'nci maddesinin 4, 5 ve 6'ncı fıkralarında; fazla veya yersiz olarak tahsil edilen vergiler, vergi kanunları uyarınca iadesi gereken vergiler ve ihtirazi kayıtla beyan edilip ödendikten sonra yargı kararına göre iade edilip yine yargı kararı uyarınca tahsili gereken vergilerin iadesinde mükelleflere faiz ödenmesine yönelik düzenlemeler yer almaktadır. Yargı kararına göre iade edilecek vergilere faiz uygulaması konusunda ise mevzuatta açık bir düzenleme bulunmamaktadır. Bugüne dek bu konuda özellikle VUK'un 112'nci maddesinin 4'üncü ve IYUK' un $28^{\prime}$ inci maddesinin 6'ncı fıkraları üzerinden fikir yürütülmeye çaIışılmış bulunmaktadır (Hatipoğlu, 2014: 436-437).

VUK'un 112'nci maddesinde düzenlenen fazla veya yersiz tahsilat, 213 sayılı Kanun'un 116 ' $\mathrm{nc}$ maddesinde tarif edilen ve 117 ile $118^{\prime}$ inci maddelerinde sayılan vergi hataları sebebiyle mükelleflerden fazla veya yersiz tahsil edilen vergileri kapsamaktadır. Zira 418 Sıra No'lu VUK Genel Tebliği'nde, yalnız bu kapsama giren vergilerin iadesinde 112'nci maddenin dördüncü fıkrasına göre faiz hesaplanması gerektiği belirtilmektedir. Diğer bir deyişle, faiz hesaplanmasını gerektiren durumların, vergi hatalarından biri ile meydana gelmiş olması zorunluluğu bulunmaktadır. Ayrıca düzenleme gereği yalnızca VUK kapsamındaki alacakların iadesinde bu hükmün uygulanması mümkün olup, 213 sayılı Kanun kapsamına girmeyen ancak 6183 sayılı Kanun'a göre tahsil edilen diğer kamu alacaklarının iadesinde ise 112 'nci maddeye istinaden faiz hesaplanması mümkün olmamaktadır (T.C. Gelir İdaresi Başkanlığı (GiB), 2012).

IYUK' un $28^{\prime}$ inci maddesinin 6'nc fıkrası ise tazminat ve vergi davalarında idarece, mahkeme kararının tebliğ tarihi ile ödeme tarihi arasındaki süreye 6183 sayılı Kanun'un 48'inci maddesine göre belirlenen tecil faizi oranında hesaplanacak faizin ödeneceğini, ancak mahkeme kararının davacıya tebliği ile banka hesap numarasının idareye bildirildiği tarih arasında geçecek süre için faiz ödenmeyeceğini belirtmektedir. Yani düzenleme mahkeme kararından kişilere yapılacak ödeme tarihine kadar olan dönem için faiz tahakkukunu hükme bağlamaktadır. Bu bakımdan hüküm, kişilerin geçmiş değil gelecek zararlarını gidermeye yöneliktir. Bu haliyle madde haksızlığa uğramış olan mükelleflerin ekonomik kayıplarını telafi etmemektedir (Hatipoğlu, 2014: 438).

Mükelleflerden tahsil yetkisinin kullanımıyla tahsil edilen kamu alacaklarının hukuka aykırı olması durumunda sakatlığı kesin olarak saptanmış bir işlem söz konusu olacağından, Hazine bakımından yükümlü aleyhine bir sebepsiz zenginleşme söz konusu olmaktadır. Bu fakirleşmeye maruz kalan mükellef açısından sadece haksız olarak malvarlığından çıkan miktarın vergi aslı ve gecikme zammının iadesi yeterli olmayıp, vergi idaresinin gözetildiği şekilde, vergi borçlusunun ekonomik kaybını gidermek üzere hazinece ona faiz ödenmesi gerekmektedir. Zira çıkar dengesi ancak bu şekilde tesis edilebilecektir. Nitekim gecikme faizini haklı göstermek üzere 3239 sayılı Kanun'un gerekçesinde ifade edilen, "Bugünkü ekonomik düzeyde her alacak, borç münasebeti faizi gerektirmekte ve alacağın tahsilinde her ne suretle olursa olsun husule gelen gecikmelerde 
faiz uygulanmaktadır" yolundaki ifadenin, madalyonun öbür yüzünü temsil eden zarara uğrayan mükellef bakımından da tümüyle geçerli kabul edilmesi mülkiyet hakkının korunması bakımından bir gerekliliktir (Kumrulu, 1988: 249).

Vergi idaresinin tahsil yetkisinin kullanımı sürecinde yapmış olduğu hukuka aykırılıklar borçluların özel hayatlarının gizliliğine zarar verilmesi ve haberleşme özgürlüklerinin engellenmesi yönünde de sonuç doğurabilmektedir. Buna göre zor alım işlemlerinde görevli memurların mükelleflere ait sırları ifşa etmesi veya haczedilen mallarla birlikte ticari değeri olmayan mükellefin özel eşyalarına da el koymaları özel hayatın gizliliğinin ihlal edilmesi anlamına gelmektedir. Yine borçluların haberleşme cihazlarının haczedilmesi de haberleşme özgürlüklerini ihlal etmektedir. 4502 sayılı Kanunun 13'üncü maddesi ile 406 sayılı Telgraf ve Telefon Kanununa Ek Madde 25 'de, telekomünikasyon hizmetleri ile ilgili olarak abone veya kullanıcılara tahsis edilen numara ve hat kullanımı gibi intifa ve kullanım haklarının hiçbir şekilde haczedilemeyeceği belirtildiğinden, 29.01.2000 tarihinden itibaren telekomünikasyon hizmetleri ile ilgili olarak abone veya kullanıcılara tahsis edilen numara ve hat kullanımı gibi intifa ve kullanım haklarının amme alacakları nedeniyle yapılan takipler sırasında haczedilmeleri mümkün olamamaktadır (T.C. GiB, 2000). Hazine ve Maliye Bakanlığı ayrıca uygulamada karşılaşılan sorunların önüne geçebilmek amacıyla zorunlu haller dışında telefonların da haczedilmemesi gerektiğini vergi dairelerine duyurmuş bulunmaktadır (T.C. GiB, 1974).

Tahsil yetkisinin kullanımı sürecinde karşılaşılan hukuka aykırılıklar borçluların çalışma haklarına da zarar verilebilmektedir. Zira uyuşmazlıklar yargıya taşındığında mükellef haklı bulunsa dahi yargılama süreci boyunca ekonomik faaliyetleri olumsuz etkilenebilmektedir. Sırf kamu alacağının elde edilmesi uğruna borçlunun tüm mal ve gelirlerine el konulması ve gereksiz zor kullanılması merhamet duygusuna aykırı olmanın yanı sıra, borçluyu hayat mücadelesi içinde başkalarının menfaatlerine zarar vermeye sevk etme tehlikesi taşıması nedeniyle de kamu düzenine aykırılık oluşturmaktadır (Aslan, 2005: 273-274).

Alacakların zor alımı sürecinde kamu borçluları özel hukuk borçlularından farklı değerlendirilmektedir. Zira özel hukuk alacaklısını, alacağını tahsil ettikten sonra borçlusunun ekonomik ve sosyal durumu ilgilendirmemektedir. Buna karşın kamu alacakları kamu idaresinin gelir kaynağını oluşturduğundan, kamu idarelerinin borçluların kamu borcu ödendikten sonraki durumlarını da düşünmeleri ve korumaları gerekmektedir. Aksi halde devletin kendi gelir kaynağını yok etme tehlikesi doğacaktır (Karakoç, 2001: 126). Bu bakımdan, borçlunun ekonomik olarak yok olması pahasına kamu alacağının tahsili yoluna gidilmesinin aslında alacaklı vergi idaresinin menfaatlerine de aykırılık teşkil ettiği açıktır. Bu nedenle zor alım işlemlerinin borçluyu ekonomik olarak yok edecek seviyeye ulaşmaması gerekmektedir (Aslan, 2005: 274). 351 Seri No'lu Tahsilat Genel Tebliğinde borçlunun varlığından rahatlıkla tahsili mümkün olan bir borç için daha ziyade ticari faaliyetini güçleştirecek ve haklı sayılabilecek şikâyetlerine sebep olacak bazı varlıklarının haczedilmemesi gerektiği belirtilmiş bulunmaktadır (T.C. GiB, 1974). Bu konuda Danıştay'ın görüşü de zorunlu bir durum söz konusu olmadıkça vergi idaresinin borçlunun ticari faaliyetinin devamı için gerekli olan malları üzerine haciz uygulamasının hukuka aykırı olduğu yönündedir (D. 4. D., 22.01.1996 tarih, E. 1995/4421, K. 1996/300'den aktaran Candan, 2011: 395). Bu noktada vergi idaresince borçluların taşıtlarına bağlamalı haciz uygulamasının başta çalışma hakkı olmak üzere insan onuru açısından da sorgulanması gerekmektedir.

Bilindiği gibi vergi borcu nedeniyle mükelleflerin taşıtları haczedilebilmektedir. 6183 sayılı Kanun'un 77'nci maddesi uyarınca vergi idaresince taşıtlara uygulanan hacizler aynı zamanda ruhsatlarına da işlenmekte ve bu sayede taşıtın vergi borcu ödenmeden satışının önüne geçilmiş 
olunmaktadır (Türkmen, 2016). Vergi idaresince konulmuş olan haczin kaldırılması için borcun ödenmesi şarttır. Diğer taraftan, aracın aynından doğan motorlu taşıt vergisi borcu ödenmediği sürece aracın kesin satışına izin verilmemekte ve yine taşıtların trafik muayenesinin yapılabilmesi için de, araçla ilgili borcun ödenmesi ya da taksitlendirilmesi istenmektedir. Bu süreçte vergi idarelerince haczedilen araçlar için trafiğe yazı çıkartılarak yakalama ve bağlama kararı da alınabilmektedir (Alpaslan M., 2013).

Vergi idarelerinin bu uygulamaları Hazine ve Maliye Bakanlığı'nca çıkarılan 351 Seri No'lu Tahsilat Genel Tebliği'nin bir sonucudur. Nitekim Bakanlık söz konusu tebliğ ile uygulamada borçluların sahibi oldukları otomobil ve kamyon gibi araçların fiilen haczedilmeyerek bunların sadece trafik kayıtlarına haciz tebliği ile yetinildiğini, trafik kaydına konulan haczin aracın çalınmasına, çarpışmak suretiyle yok olmasına ve sahibi tarafından adi senetle başkasına satılarak elden çıkarılmasına engel olamadığını belirtmiştir. Tebliğde ayrıca, Yargıtay kararlarında da trafik kaydının mülkiyetin tutanağı değil, belirtisi sayıldığı, bu nedenle aracın Trafik Kanunu hükmü uyarınca trafik kaydına tescili, yalnız aracın trafiğe çıkması açısından zorunlu olduğundan, yapılan satışların mahkemece bozdurulmasının genellikle mümkün olamadığı belirtilmiştir. Borçluya ait malın haczedilmesinde amacın kamu alacağının tahsil edilmesi olduğundan, taşıtların haczinde sadece bunların trafik kayıtlarına haciz tebliği ile yetinilmeyerek taşıtın kendisinin haczedilmesi gerektiği, bu şekilde haczedilen araç hakkında da 6183 sayılı Kanunun 82'nci maddesi uyarınca gerekli koruma önlemleri alınacağı, belirtilen şekilde uygulanmayan hacizle aracı hacizli saymaya ve bundan bir sonuç almaya imkân bulunmadığından bundan sonra aracın trafik kaydına haciz tebliği ile yetinilmeyerek, kendisinin de fiilen haczedilmesi gerektiği vergi idarelerine bildirilmiştir.

Günümüzde bu uygulama, sonuçları bakımından tartışılmaktadır. Zira vergi idarelerince haczedilen araçların yakalanması ve alıkonulması gerek borçlunun anayasal haklarına gerekse ekonomik ve ticari faaliyetlerine zarar verebilmekte, özellikle faaliyet alanını taşıma işleri oluşturan mükelleflerin ticari hayatları kayda değer şekilde sekteye uğrayabilmektedir. Her ne kadar tebliğin konuya ilişkin son kısmında işi sadece eşya ve insan nakli gibi taşımacılık olan borçlular tarafından istenmesi halinde, güvenilir bir şahsın kefaleti ile kısa bir sürede kamu alacağının ödenmesi amacıyla aracın borçluya bırakılabilmesine de imkân tanınmış olsa da, bu tarz bir uygulamanın diğer borçluların ekonomik faaliyetlerine zarar verdiği ve bu süreçte yapılan masraflara bağıı olarak borç miktarının ciddi oranda arttığı da bir gerçekliktir.

Elazığ Defterdarlığı'nca 2013 yılında yapılan bir projede haczedilen araçların satışının uzun sürmesi nedeniyle borçlunun oluşan gecikme zammının da etkisiyle zor durumda kalması sorununa değinilmiştir. Projede ayrıca; yakalamalı haciz yapılması neticesinde yediemine bırakılan araçların ekonomik faaliyetlerden çektirilmenin ötesinde, satımlarının gerçekleştirileceği zamana kadar ciddi bir otopark ücretine ek olarak rutin dönemsel bakımlarının yapılmaması nedeniyle ciddi bir şekilde aşınmaya, yıpranmaya maruz kaldıkları belirtilmiş ve mümkün olduğunca bu yola başvurulmaması gerektiğine vurgu yapılmıştır (Dönmez, 2013: 6-7).

Borçluların haczedilen araçlarının vergi idareleri tarafından yakalama işlemine dönüştürülme kararının alınması durumunda bu kararın alındığının ve Emniyet Müdürlügü̈’ne bildirilerek uygulamaya geçirildiğinin borçlulara tebliği gerekmektedir. Uygulamada vergi idarelerinin bu bildirimi yapmadan yakalama işlemi yaptırmaları (Türkmen, 2016) borçluları zor durumda bırakabilmekte ve insan onurlarına da zarar verilebilmektedir. 
Vergi idaresine tahsil yetkisi verilmesinin nedenlerinden biri de Anayasanın 73'üncü maddesinden kaynaklanan genellik ve eşitlik ilkelerine uyum gösterilerek vergi adaletinin sağlanmasıdır. Zor alım işlemleri sırasında idarenin yapmış olduğu hukuka aykırılıkların mükelleflerce yargıya taşınması sonucu ihtilafı hale gelen kamu alacaklarının vergi yargısından geçerek tahsil aşamasına ulaşması çok uzun süreler almaktadır. Bu bakımdan kamu alacağının Hazine'ye intikalinin biran evvel gerçekleştirilerek artan kamu harcamalarının finansmanının sağlanması ve toplanamayan alacakların en azından bir kısmının toplanabilmesi (Edizdoğan ve Gümüş, 2013: 102-103) amacıyla vergi aflarına başvurulmaktadır. Vergi afları, vergisini zamanında ödeyen mükellefleri mağdur eden ve vergi adaletini ortadan kaldıran uygulamalardır (Gerger, 2007: 178). Bu sebeple sık sık vergi aflarına başvurulması adaletsizliğe yol açmakta ve vergide genellik ve eşitlik gibi anayasal ilkelere aykırılık oluşturmaktadır. Bu durum mükelleflerin vergiye gönüllü uyumlarını da olumsuz etkilemektedir.

\subsection{Vergi İdaresi Açısından Sonuçlar}

Vergi idaresinin tahsil yetkisini kullanımı sürecinde ortaya çıkan olumsuz koşullardan en az mükellefler kadar vergi idarelerinin de etkilendiği bir gerçektir. Zira vergi idarelerinin tahsilatta etkinliği sağlayarak vergi gelirlerini artırma çabası ile tahsil yetkisini hukuka aykırı kullanımı; mükelleflerin mali durumlarının zarar görerek kamu alacağını ödeyemeyecek duruma gelmelerine yol açmaktadır. Bunun neticesinde idarenin gelir kaynağının kuruması, ekonomik faaliyetlerinin yavaşlamasına bağlı olarak vergi gelirlerinin azalması, yaşanan uyuşmazlıkların yargıya taşınması neticesinde alacakların Hazineye intikalinin gecikmesi ve bu durumun yol açtığı gelir ihtiyacının borçlanma ya da af kanunları ile giderilmeye çalışııması gibi sonuçlar ortaya çıkmaktadır. Tüm bu durumlar neticesinde, mükelleflerin vergiye gönüllü uyumlarının azalması ve nihayetinde mükellef hakları zarar gördüğünden idareye duyulan güvenin azalması gibi birçok istenmeyen sonuçlar doğabilmektedir. Verilen yargı kararlarının idare aleyhine olması durumunda idarenin ayrıca tazminat ödeme yükümlülüğü de doğmaktadır. Tüm bu sorunlara ilaveten Türkiye'de vergi idaresinin hukuka aykırılıklar nedeniyle kötü bir intiba bırakması yatırımları da olumsuz etkilemektedir.

Tahsil yetkisinin kullanımında yaşanan hukuka aykırılıkların idare bakımından en olumsuz sonucu kamu alacağının tahsilinin gecikmesidir. Zira diğer modern bütçe sistemlerinde olduğu gibi Türk bütçe sisteminde de giderlerin önceliği esas olduğundan, ortaya çıkan kamu geliri açığının başka yollardan kapatılması zorunluluğu söz konusu olmaktadır. Bu yöntemlerden bir tanesi borçlanmadır. Ancak kamu borçlanmasının sürekli artan kamu açıkları ve gelecek nesiller üzerinde vergi yükü gibi bazı olumsuz ekonomik sonuçları bulunmaktadır (Şimşek, 2009: 48-55). Vergi idaresinin borçlanmanın olumsuz sonuçlarından kaçınabilmek adına tahsil yetkisinin kullanımında sınırları aşarak yapmış oldukları işlemler mükelleflerce yargıya taşınabilmekte, bunun neticesinde ise kamu alacağının tahsili gecikebildiği gibi hiç tahsil edilmemesi de söz konusu olabilmektedir. Bu durum da tüm olumsuz sonuçlarına rağmen borçlanma yoluna gidilmesine yol açabilmekte ve nihayetinde idare üzerinde tahsilat baskısı artmaktadır.

Gelir açığının kapatılması amacıyla hükümetlerin başvurdukları bir diğer yol ise vergi aflarıdır. Vergi aflarına başvurulmasında ekonomik, mali, siyasi, teknik ve sosyal birçok neden bulunmakla birlikte, vergi idaresi ve yargısının çok büyük bir iş yükü altında bulunmalarına bağlı olarak gerek kamu alacaklarının takip ve tahsilinin, gerekse ihtilaflı kamu alacaklarının yargıdan geçerek tahsil edilmesinin çok uzun süreleri kapsar hale gelmesi de af kanunlarına başvurulmasının nedenlerinden birini oluşturmaktadır (Martin, 2013: 23). Bu sayede vergi idaresince tahsili imkânsız hale gelmiş olan alacakların en azından bir kısmının tahsil edilerek, bütçe açıklarının 
kapatılmasının ve vergi alacağının zamanında tahsilinin sağlanması amaçlanmaktadır (Eker, 2006: 29).

Vergi aflarının devletin gelirlerini artırıcı bir araç olarak kullanılması, vergi hukuku yazınında çokça tartışılmaktadır (Yaraşır, 2013: 177). Zira vergi aflarının olumlu etkilerinin yanı sıra, bazı olumsuz sonuçları da bulunmaktadır. Bu olumsuz sonuçların en önemlilerinden biri mükelleflerin vergiye gönüllü uyumlarının azalmasına yol açmasıdır. Zira çıkarılan vergi afları bir taraftan borcunu ödemeyen mükellefler açısından ziyaa uğrattıkları vergiyi gönüllü olarak ödemeleri için bir zaman fırsatı yaratırken (Arıkan ve Yurtsever, 2004: 60), diğer taraftan mükelleflerin vergi aflarının bir defalık bir fırsat olmadığına inanmalarına neden olmakta ve çıkarılan her af yeni bir af beklentisi oluşmasına yol açmaktadır (Edizdoğan ve Gümüş, 2013: 109). Sonuç olarak sık başvurulan vergi afları her ne kadar kısa vadede devletin gelir sorununu çözüyor gibi görünse de, uzun vadede yine vergi idaresinin kaybetmesine neden olmaktadır.

İdarenin tahsil yetkisinin kullanımı sürecinde yapmış olduğu hukuka aykırılıklar idareye duyulan güvenin azalmasına ve idarenin mükelleflerle olan ilişkilerinin bozulmasına da yol açmaktadır. İdareye güven duyan mükelleflerin daha çok vergi ödediği gerçeğinden yola çıkıldığında, mükelleflerin idareye duydukları güvenin artırılması gerektiği açıktır (Tosuner ve Arıkan, 2003: 71). Günümüz modern vergileme işlemlerinde vergi idareleri başarı sağlanabilmesi için mükelleflerle işbirliğine gidilmesi ve onların vergiye gönüllü uyumlarının artırılmasının şart olduğunu farkına varmış ve vergileme işlemlerinde "mükellefe rağmen" değil, "mükellefle birlikte" hareket etmeyi ve mükelleflerin beklentilerini dikkate almayı hedeflemişlerdir. Bu kapsamda; vergileme işlemine mükellef açısından yaklaşılması ve mükelleflerin vergi idarelerine güven duyarak vergiye gönüllü uyumlarının artırılması için mükellef hakları ön plana çıkmıştır (Gerçek, 2006). Zira vergiye gönüllü uyum, mükellef haklarına saygı gösterildiği ve çerçevesi sağlam temellere oturtulduğu ölçüde artmaktadır (Arıkan ve Gürbüz, 2014: 141).

Mükellef hakları, zaman içerisinde belge kapsamına alınma özelliği kazanarak "Mükellef Hakları Bildirgesi" adıyla vergi yazınına girmiştir. Bu belgeler vergi kanunlarının içerisinde yasal bir metin şeklinde olabildiği gibi, gelir idareleri tarafından ilan ve taahhüt edilen idari nitelikli bir belge şeklinde de olabilmektedir. Her ne şekilde olursa olsun özünde bu bildirgeler bir taraftan mükellef haklarını sıralayan, diğer taraftan ise ilgili idarenin bunları korumak noktasındaki yükümlülükleri hatırlatan temel birer belge niteliğindedir (Avcı, 2019: 113).

Türkiye'de GiB, mükellef idare ilişkilerinin güçlendirilmesi ve vergiye gönüllü uyumun artırılması için almış olduğu önlemler kapsamında 2006 yılında "Mükellef Hakları Bildirgesi" yayımlamıştır. GiB tarafından atılan bu adım vergiye gönüllü uyumun sağlanması bakımından önemli bir aşama oluşturmaktadır.

Söz konusu bildirge, hukuki bağlayıcılığı olan bir metin olmayıp, idarenin mükelleflere karşı taahhüdünü deklare etmesi anlamını taşımaktadır (Aykın, 2017). Burada temel beklenti, mükellef ile idare arasında oluşturulacak güven ortamı ile işbirliğinin sağlanması ve vergi sorunlarının mükellef bakımından değerlendirilerek mükellef haklarının açık bir biçimde tanımlanıp, korunmasıdır (Çetin ve Gökbunar, 2010: 26).

Yayımlanan bildiride; VUK'un öngördüğü haller dışında şahsi ve gizli bilgilerin korunacă̆ı, vergi ile ilgili yükümlülüklerin yerine getirilmesinde mükelleflere her türlü kolaylığın sağlanacağı gibi bir dizi taahhütte bulunulmaktadır (T.C. GiB, 2006). Bu kapsamda Başkanlık ayrıca bir rehber yayımlayarak mükelleflerin hakları ve ödevlerini ayrıntılı olarak düzenlemiş ve mükelleflerin haksız bir uygulama ile karşılaştıklarında başvuruda bulunabilecekleri mercilere yer vermiştir 
(T.C. GiB, 2010). Tablo 1'de GiB tarafından yayımlanan rehberde yer alan genel ve özel haklar yer almaktadır.

Tablo 1: Mükelleflerin Hakları

\begin{tabular}{cccc}
\hline & Genel Haklar & Özel Haklar (Vergi Kanunlarında Yer Alan \\
Haklar)
\end{tabular}

Kaynak: T.C. GiB, 2014: 7-8

Tablodan da görüleceği gibi, mükelleflere vergiye gönüllü uyumlarının sağlanması amacıyla bir takım haklar tanınmış bulunmaktadır. Mükellef odaklı, kaliteli hizmet sunma anlayışını benimseyen GiB'in bu çabalarının tahsil yetkisinin kullanımı sürecinde yapılan hukuka aykırılıklar neticesinde zarar görmesi kaçınılmaz olmaktadır.

Vergiye gönüllü uyumun azalması kamu gelirlerini azaltacağından bütçe açığının artmasına yol açmaktadır. Bütçe açı̆̆ını kapatmak için hükümetlerin başvurdukları diğer yollar yeni vergiler koymak ya da vergi oranlarını artırmaktır (Eğilmez, 2016). Ancak hükümetlerin vergileri artırarak bütçe açı̆̆ı ile mücadele etmelerinin birtakım olumsuz sonuçları mevcuttur. Her şeyden önce bu durum mükelleflerin vergilerini ödememe eğilimlerini körüklediğinden zor alım işlemleri ve buna bağı olarak ortaya çıkan sorunların artmasına sebep olabilecektir. Ayrıca vergi oranları doğrudan yabancı yatırımların önemli belirleyicilerinden biri olduğundan, daha yüksek vergi oranları, doğrudan yabancı yatırımlar üzerinde de olumsuz etkide bulunmaktadır (Özcan ve Arı, 2010: 68, 71). Doğrudan yabancı yatırımlarının azalması ise istihdam kapasitesi ve vergi gelirlerini azaltarak ekonomiye zarar vermektedir.

O halde, tahsil yetkisinin kullanımı sürecinde yapılan hukuka aykırılıklar ekonominin de zarar görmesi sonucunu doğurmaktadır. Daha etkili vergi ve tahsil sistemlerinin işletmelere yarar sağladığı ve neticede ekonomik gelişme ve yatırımı teşvik ettiği bilinmektedir. Bu bakımdan dünya çapındaki ekonomiler, şirketler üzerindeki vergi uyum yükünü basitleştirmek ve hafifletme yönünde çalışmalar yapmaktadır (PricewaterhouseCoopers (PWC), 2017). Bu noktada Dünya Bankası ve PWC tarafından hazırlanan "Vergi Ödemeleri Raporu" ülke uygulamalarına yer vererek 
ülkelerin vergi ödeme kolaylığı bakımından konumlarını ve işletmeleri üzerindeki vergi uyumu yükünü basitleştirme noktasındaki ilerlemelerini ortaya koyması bakımından önem taşımaktadır.

Dünya Bankası ve PWC tarafından yayımlanan 2017 yılı raporuna göre Türkiye vergi ödeme kolaylığı bakımından 190 ekonomi arasında 128'inci sırada yer almaktadır. İlk 3 sırada ise Katar, Birleşik Arap Emirlikleri ve Hong Kong bulunmaktadır. Rapora göre, ülkelerin ortalama olarak ödedikleri toplam vergi oranı \% 40,6 olarak gerçekleşirken ortalama olarak vergi ödemeleri için harcanması gereken zaman 251 saat, ödenen vergi sayısı ise 11 'dir. Türkiye'de ise işletmelerinin ortalama vergi oranı \% 41,1, vergi ödemeleri için harcadıkları zaman 217 saat ve ödenen toplam vergi sayısı ise $11^{\prime}$ dir (World Bank Group ve PWC, 2017). Bu veriler Türkiye'de şirketlerin ticari faaliyette bulunmalarının vergi kolaylığı açısından cazip olmadı̆̆ını göstermektedir. Mevcut sistem yeterince zorken mükelleflerin bir de vergi idarelerinin yanlış uygulamalarıyla caydırılmalarının ekonomiye zarar vereceği düşünülmektedir.

Vergi idaresinin kamu gelirlerinin kaynağı mükellefler olduğundan, zor alım işlemlerinde yapılan hukuka aykırılıklarla borçlunun ekonomik durumunun zarar görmesi, diğer bir ifadeyle, borçlunun ekonomik olarak yok olması pahasına kamu alacağının tahsili için zor alım işlemlerine devam edilmesi alacaklı vergi idaresinin menfaatlerine de zarar vererek uzun vadede vergi gelirlerini olumsuz etkilemektedir (Aslan, 2005: 274).

Tahsil yetkisinin kullanımı sürecinde yapılan hukuka aykırılıkların idare açısından diğer olumsuz sonucu idarenin haksız çıkması sonucu ödenen tazminatlardır. Vergi uyuşmazlıklarında haksız olduğunu bilen mükellefler idari aşamada çözüm yolarını tercih ederken, kendilerinin haklı olduğunu düşünen mükellefler ise uyuşmazlıkları yargıya taşımaktadırlar. Büyük Mükellefler Vergi Dairesi Başkanlığı'nın 2015 yılı faaliyet raporuna göre 2015 yılında sonuçlanan toplam 1072 davadan 746 tanesi yani yaklaşık \% 70'i mükellef lehine sonuçlanırken, 326 tanesi yani yaklaşık \% 30'u ise mükellef aleyhine sonuçlanmış bulunmaktadır (T.C. GiB, 2016: 15). Anayasa'nın 125'inci maddesinde de idarenin eylem ve işlemlerinden doğan zararları ödemekle yükümlü olduğu belirtildiğinden, vergi idaresinin hukuka aykırı işlemleri nedeniyle mükelleflere tazminat ödemesi zorunluluğu bulunmaktadır.

Yaşanan uyuşmazlıkların yargıya taşınması ile yargının iş yükünün ağırlaşması neticesinde davaların sonuçlanması uzun zaman almaktadır. Bu durum idarenin ayrıca yargılamaların uzun sürmesi nedeniyle tazminat ödemesi sonucu da doğurmaktadır. Anayasa Mahkemesince vergi uyuşmazlıklarına ilişkin yapılan bireysel başvuru denetimlerinde verilen ihlal kararlarının büyük bir çoğunluğunu makul sürede yargılanma haklarının ihlali oluşturmaktadır (Tekbaş ve Hayrullahoğlu, 2018: 267). Bu bakımdan vergi idaresinin hukuka aykırı işlemler yapması neticesinde davayı kazanacağına emin olan mükelleflerin uyuşmazlığı yargıya taşıması hem alacağın tahsil imkânının ortadan kalkmasına ya da gecikmesine yol açmakta hem de idarenin gerek eylem ve işlemleri nedeniyle gerekse yargının iş yüküne bağlı olarak uyuşmazlığın çözümünün uzun sürmesi nedeniyle tazminat ödemesine neden olmaktadır.

\subsection{Vergi Yargısı Açısından Sonuçlar}

Tarih boyunca devletlerin hazineci bir yaklaşımla, kişilerin temel hak ve özgürlüklerini ihlal ederek vergi toplamaları, anayasacılık hareketlerinin yanı sıra, vergi hukuku ve buna bağlı olarak vergi yargısının oluşumunda da etkili olmuş (Özkan, 2005: 4-5), bireylerin keyfi uygulamaları yargıya taşıma imkân ve bilinçlerinin artmasına bağlı olarak da her geçen yıl vergi uyuşmazlıklarının da çözümlendiği idari yargının iş yükü artmaya başlamıştır. Bu bakımdan vergi idaresinin 
tahsil yetkisinin kullanımı sürecinde yapmış olduğu hukuka aykırılıklar vergi uyuşmazlıklarını çözmekle görevli yargı organlarını olumsuz etkilemektedir.

İdari yargının iş yükünün artmasının başlıca sebepleri olarak; toplumun hak arama konusunda bilincinin artması, iletişim olanakları ve ulaşım kolaylığı nedeniyle dava açmanın daha kolay ve az maliyetli bir hale gelmesinin yanı sıra idarenin hukuka aykırı işlemlerinin artması gösterilmektedir (Sarısoy, 2014: 16-17).

İdari yargıda iş yükünün artması yargı organlarının yanı sıra idareyi ve mükellefleri de olumsuz etkilemektedir. Zira iş yükü sebebiyle ihtilafların çözüm sürelerinin uzunluğuna bağlı olarak idare açısından alacağın tahsili gecikmesi ve makul sürede yargılanma hakkının ihlali nedeniyle tazminat ödenmesi; mükellefler bakımından ise yargılamanın kaybı durumunda daha büyük miktarlarda kamu borcu ile karşılaşılması ya da faiz alınamaması nedeniyle alacağın değer kaybetmesi gibi istenmeyen sonuçlar ortaya çıkmaktadır.

Tablo 2: Mahkeme Türüne Göre Mahkemelere Gelen, Karara Bağlanan ve Gelecek Yıla Devredilen Dava Sayıları (2009-2018)

\begin{tabular}{|c|c|c|c|c|c|c|c|c|c|c|}
\hline $\begin{array}{l}\text { Mahkeme } \\
\text { Türü }\end{array}$ & 2009 & 2010 & 2011 & 2012 & 2013 & 2014 & 2015 & 2016 & 2017 & 2018 \\
\hline $\begin{array}{c}\text { Toplam } \\
\text { Gelen } \\
\text { (Ceza+Hu } \\
\text { kuk+Idari) }\end{array}$ & 6.211 .965 & 6.619 .412 & 6.645 .927 & 6.511 .186 & 6.393 .207 & 6.498 .918 & 6.587 .422 & 6.718 .079 & 7.045 .766 & 7.369 .647 \\
\hline $\begin{array}{c}\text { Karara } \\
\text { Bağlanan }\end{array}$ & 3.796 .985 & 3.882 .946 & 4.035 .127 & 4.155 .876 & 4.025 .782 & 4.109.445 & 4.101.549 & 3.871 .851 & 4.020 .590 & 4.207.127 \\
\hline $\begin{array}{c}\text { Gelecek } \\
\text { Yıla Devir }\end{array}$ & 2.414 .980 & 2.736 .466 & 2.610 .800 & 2.355 .310 & 2.367 .425 & 2.389 .473 & 2.485 .873 & 2.846 .228 & 3.025 .176 & 3.162 .520 \\
\hline $\begin{array}{l}\text { Toplam } \\
\text { Gelen } \\
\text { (İdari) }\end{array}$ & 515.918 & 585.233 & 584.963 & 533.426 & 579.036 & 582.183 & 639.988 & 786.644 & 814.718 & 736.809 \\
\hline $\begin{array}{c}\text { Karara } \\
\text { Bağlanan }\end{array}$ & 355.473 & 386.884 & 415.672 & 405.791 & 414.644 & 434.139 & 471.726 & 576.725 & 627.249 & 541.466 \\
\hline $\begin{array}{c}\text { Gelecek } \\
\text { Yıla Devir }\end{array}$ & 160.445 & 198.349 & 169.291 & 127.635 & 164.392 & 148.044 & 168.262 & 209.919 & 187.469 & 195.343 \\
\hline
\end{tabular}

Not: Bölge idare mahkemelerindeki istinaf incelemeleri 2577 sayılı Kanun'un Geçici 8'inci maddesi uyarınca 20 Temmuz 2016 tarihinden itibaren başlanılmış ve bu veriler de tabloya dâhil edilmiştir.

Kaynak: T.C. Adalet Bakanlığı, 2019: 4

Tablo 2'den de görüleceği üzere 2009-2018 arası on yıllık dönemde Bölge idare, İdare ve Vergi mahkemelerinden oluşan idari yargı mahkemelerinin toplam dava sayısında artış söz konusudur. 2009 yılında idari yargı mahkemelerine gelen toplam dava sayısı 515.918 iken, 2018 yılında bu sayı \%42.8'lik artışla 736.809 olmuştur (T.C. Adalet Bakanlığı, 2019: 4).

Tablo 3: Danıştay Dairelerine Gelen, Karara Bağlanan ve Gelecek Yıla Devredilen Davalar (2009-2018)

\begin{tabular}{ccccccccccc}
\hline Daire & 2009 & 2010 & 2011 & 2012 & 2013 & 2014 & 2015 & 2016 & 2017 & 2018 \\
\cline { 2 - 8 } $\begin{array}{c}\text { Toplam Ge- } \\
\quad \text { len }\end{array}$ & 275.598 & 297.841 & 345.187 & 350.142 & 357.495 & 333.128 & 378.132 & 464.377 & 352.306 & 305.042 \\
$\begin{array}{c}\text { Karara Bağ- } \\
\text { lanan }\end{array}$ & 106.959 & 103.880 & 137.921 & 140.815 & 167.446 & 142.951 & 184.218 & 200.019 & 146.237 & 140.029 \\
$\begin{array}{c}\text { Gelecek Yıla } \\
\text { Devir }\end{array}$ & 168.639 & 193.961 & 207.266 & 209.327 & 190.049 & 190.177 & 193.914 & 264.358 & 206.069 & 165.013 \\
\hline
\end{tabular}

Not: Vergi ve İdari Dava Daireleri Genel Kurulunda esastan açılan davaları kapsamaktadır.

Kaynak: T.C. Adalet Bakanlığı, 2019: 3. 
Benzer durum vergi yargısının temyiz organı olan Danıştay için de söz konusudur. Tablo 3'de yer alan verilere göre Danıştay dairelerine 2009 yılında gelen toplam dosya sayısı 275.598 iken, 2018 yılında bu rakam \%10,7'lik bir artış ile 305.042'ye ulaşmıştır. Bu dosyalardan 140.029' u karara bağlanırken, 165.013 dava ise 2019 yılına devretmiştir (T.C. Adalet Bakanlığı, 2019:1).

\section{Sonuç}

Devletin sahip olduğu yetkilerin en önemlilerinden biri vergilendirme yetkisidir. Ancak bu yetkinin etkin kullanımı için vergi konulması yeterli olmayıp, bu vergilerin tahsil edilebilmesi de önem taşımaktadır. Bu noktada devletin sahip olduğu tahsil yetkisi kamu hizmetlerinin sunumu için yapılacak olan kamu harcamalarının finansmanı için gerekli olan kamu gelirlerinin belirlenen zamanlarda ve etkin bir şekilde tahsilini sağlamaktadır.

Her yetkinin olduğu gibi tahsil yetkisinin de kullanımında bir takım sınırlar bulunmaktadır. Verginin tahsil edilmesi her şeyden önce kişilerin başta mülkiyet hakları olmak üzere bazı anayasal haklarına müdahale edilmesi anlamına gelmektedir. Bilindiği gibi Anayasanın 13'üncü maddesi bireylerin temel hak ve özgürlüklerini sınırlandırmanın sınırlarını çizmektedir. Bu çerçevede tahsil yetkisinin kanunda belirlenen şekillerde ve ölçüde kullanılması önem kazanmaktadır. Yetkinin kanunda belirlenen şekillerde kullanılabilmesi, idari işlemler için geçerli olan kurallara uygun kullanılması halinde mümkün olabilmektedir. Zira yetki kullanımında yapılan her bir işlem idari bir işlem niteliği taşımaktadır. Yine yetkinin kanunda belirlenen şekillerde kullanıldığından söz edilebilmesi için yetkinin kullanımını erteleyen ya da sona erdiren bazı durumların gerçekleşmesi durumunda zor alım işlemlerine devam edilmemesi de gerekmektedir.

Belirtilen tüm bu sınırlara uyulmaması bir takım hukuka aykırılıklar yaratarak mükelleflerin haklarına zarar verilmesinin yanı sıra idare ve yargı organlarının da olumsuz etkilenmelerine yol açmaktadır.

İdarenin tahsil yetkisini kullanımı sürecinde yapmış olduğu hukuka aykırılıklar nedeniyle mükelleflerin mülkiyet haklarının yanı sıra; insan onuru, kişiliğin ve kişi özgürlüklerinin korunması, özel hayatın ve haberleşme özgürlüğünün korunması, hak arama özgürlüğü, ailenin korunması ve çalışma hakkı gibi hakları zarar görebilmektedir.

Idare açısından ise mükelleflerin ekonomik faaliyetlerinin yavaşlamasına bağlı olarak vergi gelirlerinin azalması, yaşanan uyuşmazlıkların yargıya taşınması neticesinde alacakların Hazineye intikalinin gecikmesi ve bu durumun yol açtığı gelir ihtiyacının borçlanma ya da af kanunları ile giderilmeye çalışılması gibi sonuçlar ortaya çıkmaktadır. Tüm bu durumlara bağlı olarak, mükelleflerin vergiye gönüllü uyumlarının ve idareye duydukları güvenin azalması gibi birçok istenmeyen sonuç doğabilmektedir. Ayrıca yargı kararlarının idare aleyhine olması durumunda idarenin tazminat ödeme yükümlülüğünün doğması ve vergi idaresinin bırakmış olduğu kötü intiba nedeniyle yatırımların olumsuz etkilenmesi de söz konusu olabilmektedir.

Bireylerin, idarenin keyfi uygulamalarını yargıya taşıma imkân ve bilinçlerinin artmasına bağlı olarak da vergi uyuşmazlıklarının da çözümlendiği idari yargının iş yükünün artması yargı organlarını da olumsuz etkilemektedir. 


\section{Kaynaklar}

Ağar, Serkan (2009), Vergi Tahsilâtından Kaynaklanan Uyuşmazlıklar ve Çözüm Yolları, Ankara: Yaklaşım Yayıncılık.

Alpaslan, Mustafa (2013. 6 Şubat). "Taşıt Araçlarının Vergi Borcundan Bağlamalı Haciz Uygulaması Nedir?”, MuhasebeTR, http://www.muhasebetr.com/yazarlarimiz/mustafaalpaslan/093/, (Erişim: 11.07.2017).

Alpaslan, Nazlı Gaye (2017. 3 Mayıs), “Amme Alacaklarının Takibinde: Ödeme Emri ve \%10 Haksız Çıkma Zammı”, MuhasebeTR, http://www.muhasebetr.com/yazarlarimiz/nazligayealpaslan/0104/, (Erişim: 10.07.2017).

Anayasa Mahkemesi (1963. 11 Ekim), “E: 1963/124, K: 1963/243 sayılı Karar”, http://www.anayasa.gov.tr /icsayfalar/kararlar/kbb.html, (Erişim: 02.09.2015).

Anayasa Mahkemesi (2011. 10 Şubat), “E: 2008/58, K: 2011/37 sayılı Karar”, http://www.anayasa.gov.tr/icsayfalar/kararlar/kbb.html, (Erişim:11.07.2017).

Arıkan, Zeynep; Yurtsever, Hatice (2004), “Türkiye'de Mali Affın Nedenleri, Etkileri Ve Sonuçları-I” Yaklaşım, S. 136: 5964.

Arıkan, Zeynep; Gürbüz, Salih (2014), "Vergi Mükellefinin Hakları”, (Ed. Kâmil Tüğen; Asuman Altay), Prof. Dr. Fevzi Devrim'e Armağan, İzmir: Dokuz Eylül Üniversitesi İktisadi ve İdari Bilimler Fakültesi Maliye Bölümü: 141-146.

Arslaner, Hakan (2010), Kamu Alacaklarının Haciz Yolu ile Takibi, (Yayınlanmamış Doktora Tezi), T.C. Marmara Üniversitesi Sosyal Bilimler Enstitüsü, İstanbul.

Aslan, Kudret (2005), "Hacizde Sıra (Tertip)”, Ankara Üniversitesi Hukuk Fakültesi Dergisi, C. 54, S. 2: 269-318.

Avcl, Orçun (2019), Türkiye'de ve Seçilmiş Ülkelerde Vergi Inceleme Sürecinde Mükelleflerin Hak ve Ödevleri, İstanbul: On İki Levha Yayıncılık.

Aykın, Hasan (2017.16 Mart), “Mükellef Hakları Bildirgesinde İmzalar Eksik mi?”, Vergi Dosyası, https://vergidosyasi.com/2017/03/16/mukellef-haklari-bildirgesindeimzalar-eksik-mi/, (Erişim: 14.07.2017).

Azrak, Ülkü (2010), "Türk Hukuku'nda Temel Hak ve Özgürlüklerden Kaynaklanan Sınırlar”, (Ed. Bahri Öztürk; Funda Başaran Yavaşlar), Vergi Hukuku Örneğinde Hukuka Uygun ve Etkin Kamu Denetimi Sempozyumu, Ankara: Seçkin Yayıncılık: 96-105.

Batun, Mehmet (2010), "Vergi Yargılamasına Egemen Olan Ilkeler", Yaklaşım, S. 206: 258 - 264.

Bayraklı, Hasan Hüseyin; Odabaş, Hakkı (2000), “Vergilendirme Yetkisi ve 1982 Anayasası”, Afyon Kocatepe Üniversitesi iktisadi ve Idari Bilimler Fakültesi Dergisi, C. 2, S.1: 141-156.

Bayraklı, Hasan Hüseyin (2009), Genel Vergi Hukuku, Afyonkarahisar: Celepler Matbaacılık.

Candan, Turgut (2011), Açıklamalı Amme Alacaklarının Tahsil Usulü Hakkında Kanun, Ankara: Maliye ve Hukuk Yayınları.

Çağan, Nami (1980), “Demokratik Sosyal Hukuk Devletinde Vergilendirme”, Ankara Üniversitesi Hukuk Fakültesi Dergisi, Ci. 37, S. 1-4: 129-151.

Çetin, Güneş; Gökbunar, Ramazan (2010), “Mükellef Haklarına Vergi İdaresi Çalışanlarının Bakışı”, Yönetim ve Ekonomi, C. 17, S. $1: 23-45$.

Danıştay Dördüncü Dairesi (2011. 6 Ekim), “E: 2011/5499, K: 2011/6892 sayılı Karar”, http://emsal.danistay.uyap.gov.tr/VeriBankasilstemciWeb/GelismisDokumanAraServlet, (Erişim: 11.07.2017).

Dönmez, Güngör (2013), “6183 sayılı Amme Alacaklarının Tahsil Usulü Hakkındaki Kanun Kapsamında Gerçekleştirilmekte Olan Menkul ve Gayrimenkul Hacizlerinin Oluşturduğu Sıkıntıların Bertaraf Edilmesine İlişkin Proje Sunumu”, T.C. Elazığ Valiliği Defterdarlık Genel Müdürlüğü, http: //www.elazigdefterdarligi.gov.tr/dosyalar/projeler/gelirproje6.pdf, (Erişim: 13.06.2017).

Edizdoğan, Nihat; Gümüş, Erhan (2013), "Vergi Afları ve Türkiye'de Vergi Aflarının Değerlendirilmesi”, Maliye Dergisi, S.164: 99-119.

Eğilmez, Mahfi (2016. 9 Haziran), “Bütçe Açıkları Borçlanarak mı Para Basarak mı Finanse Edilmeli?”, Kendime Yazılar, http://www.mahfiegilmez.com/2016/06/butce-acklarborclanarak-m-para-basarak.html, (Erişim: 14.07.2017).

Eker, Cemali (2006), Türkiye'de Vergi Aflarının Sosyal ve Ekonomik Etkileri, (Yayınlanmamış Yüksek Lisans Tezi), T.C. Uludağ Üniversitesi, Sosyal Bilimler Enstitüsü, Bursa.

Emiroğlu, Haluk (2002), "Roma Hukuku'nun Bilgi Kaynaklarından Corpus luris Civilis ve Türkiye'de Hukuk Resepsiyonu”, Ankara Üniversitesi Hukuk Fakültesi Dergisi, C.51, S. 3: 85-96.

Gerçek, Adnan (2006), "Vergilemede Mükellef Hakları ve Türkiye'deki Durumun İncelenmesi”, MuhasebeTR, http://www.muhasebetr.com/ozelbolum/014/, (Erişim: 18.03.2020). 


\section{Eskişehir Osmangazi Üniversitesi IïBF Dergisi}

Gerçek, Adnan (2010), "Vergi Hukuku Alanındaki Takdir Yetkisinin Kullanılmasında İdarenin ve Memurun Sorumluluğu”, Uludağ Üniversitesi Iktisadi ve Idari Bilimler Fakültesi Dergisi, C. 29, S. 2: 23-50.

Gerçek, Adnan (2011), Kamu Alacaklarının Takip ve Tahsil Hukuku, Bursa: Ekin Yayınevi.

Gerger, Güneş Çetin (2007), "Vergi Aflarının Vergi Mükelleflerinin Tutum ve Davranışları Üzerindeki Etkisi”, Yönetim ve Ekonomi, C. 14, S. 2: 171-187.

Giritli, İsmet; Bilgen, Pertev; Akgüner, Tayfun (2006), Idare Hukuku, İstanbul: Der Yayınları.

Gözübüyük, A. Şeref; Tan, Turgut (2011), Idare Hukuku Cilt I, Genel Esaslar, Ankara: Turhan Kitabevi.

Günday, Metin (2017), Idare Hukuku, Ankara: İmaj Yayıncılık.

Hatipoğlu, Cengizhan (2014), "Yargı Kararına Göre l̇ade Edilecek Vergilerde Faiz”, İstanbul Üniversitesi Hukuk Fakültesi Mecmuası, C. 72, S. 1: 435- 447.

Karahanoğulları, Onur (2012), Idarenin Hukukla Kavranması: Yasallık ve Idari Işlemler, Ankara: Turhan Kitabevi.

Karakoç, Yusuf (2000), Kamu Alacakıarının Tahsili Aşamasında Ortaya Çıkan ve Vergi Yargısında Çözümlenen UyuşmazIıklar, Ankara: Yetkin Yayınları.

Karakoç, Yusuf (2001), “Kamu Alacaklarının Tahsili: Kamu İcra Hukuku”, Vergi Sorunları, S. 153: 116-135.

Karakoç, Yusuf (2013), “Anayasal Vergilendirme İlkeleri Üzerine Bir Değerlendirme”, Dokuz Eylül Üniversitesi Hukuk Fakültesi Dergisi, C. 15: 1259- 1308.

Karakoç, Yusuf (2016), Kamu İcra Hukuku, Ankara: Yetkin Yayınları.

Kızılot, Şükrü; Şenyüz, Doğan; Taş, Metin; Dönmez, Recai (2008), Vergi Hukuku, Ankara: Yaklaşım Yayıncılık.

Korkusuz, M. Refik (1998), Uluslararası Belgelerde ve Türk Anayasası'nda Temel Hak ve Özgürlükler, İstanbul: Özrenk Matbaacılık.

Kumrulu, Ahmet G. (1979), "Vergi Hukukunun Bir Kısım Anayasal Temelleri”, Ankara Üniversitesi Hukuk Fakültesi Dergisi, C. 36, S. 1-4:147-162.

Kumrulu, Ahmet G. (1981), “Vergi İcra Hukukuna Kavramsal Bir Yaklaşım”, Prof. Dr. Akif Erginay'a 65'inci Yaş Armağanı, Ankara: Ankara Üniversitesi Hukuk Fakültesi Yayınları No: 460: 647-668.

Kumrulu, Ahmet (1988), "Vergi Davalarında Uygulanan Gecikme Faizi Hakkında Düşünceler”, Ankara Üniversitesi Hukuk Fakültesi Dergisi, C. 40, S. 1-4: 237-250.

Martin, Ahmet (2013), Türkiye'de 2000 Yılından Sonra Uygulanan Vergi Aflarının Vergi Tahsilatı ve Vergi Uyumu Üzerindeki Etkileri, (Yayınlanmamış Yüksek Lisans Tezi), T.C. Dokuz Eylül Üniversitesi Sosyal Bilimler Enstitüsü, İzmir.

Onar, Sıddık Sami (1966), Idare Hukukunun Umumi Esasları, Cilt III, İstanbul: Hak Kitabevi.

Ökçesiz, Hayrettin (1998), "İnsan ve Hukuk Devleti”, (Ed. Hayrettin Ökçesiz), Hukuk Devleti Hukuk Felsefesi ve Sosyolojisi Arkivi Yayınları: 4, İstanbul: Afa Yayınları: 35-43.

Öncel, Mualla; Kumrulu, Ahmet; Çağan, Nami (2011), Vergi Hukuku, Ankara: Turhan Kitabevi.

Öner, Erdoğan (2017), Vergi Hukuku, Ankara: Seçkin Yayıncılık.

Özcan, Burcu; Arı, Ayşe (2010), “Doğrudan Yabancı Yatırımların Belirleyicileri Üzerine Bir Analiz: OECD Örneği”, istanbul Üniversitesi Iktisat Fakültesi Ekonometri ve Istatistik Dergisi, S. 12: 65-88.

Özekes, Muhammet (2009), Icra Hukukunda Temel Haklar ve Illkeler, Ankara: Adalet Yayınevi.

Özkan, Şener (2005), Vergi Yargılama Hukukunda Re'sen Araştırma ilkesi, (Yayınlanmamış Yüksek Lisans Tezi), T.C. Ankara Üniversitesi Sosyal Bilimler Enstitüsü, Ankara.

PricewaterhouseCoopers (PWC) (2017. 13 Şubat), "2017 Vergi Ödemeleri Raporu Basın Bülteni", https://www.pwc.com.tr/tr/basin-odasi/2017-basin-bulteni/vergi-uyumu316sirketler-icin-kolaylassa-da-yeni-veriler-beyan-sonrasi-zorluklara-isaret-ediyor.html, (Erişim: 11.07.2017).

Sarısoy, Taner (2014), “idari Yargıda İstinaf'।ı Sistem”, Vergi Raporu, S. 176: 16-32.

Savaş, H. Hüseyin (2001), "Kamu Alacaklarında İptal Davası”, Mevzuat Dergisi, S. 48, http://www.mevzuatdergisi.com /2001/12a/01.htm, (Erişim: 03.03.2016).

Şimşek, Hayal Ayça (2009), Teoride ve Uygulamada Kamu Borçlanması, Ankara: Gazi Kitabevi.

Tavşancı, Aykut (2005), "Vergilendirme Yetkisinin Anayasal Sınırları ve 1982 Anayasası", Vergi Sorunları, S. 203: 134151. 
Taylar, Yıldırım (2007), “Anayasa Mahkemesi Kararları Işığında Vergi Hukukunda Hukuki Güvenlik illkesi”, Vergi Dünyası, S. 307: 196-214.

T.C. Adalet Bakanlığı (2019), "Adalet İstatistikleri 2018”, Adli Sicil ve İstatistik Genel Müdürlüğü, http://www.adlisicil.adalet.gov.tr/Resimler/SayfaDokuman/2182019092321bulten2018.pdf, (Erişim: 18.03.2020).

T.C. Gelir İdaresi Başkanlığı (1974. 16 Eylül), “351 Seri No'lu Tahsilat Genel Tebliği”, R.G. http://www.gib.gov.tr/gibmevzuat, (Erişim: 22.06.2017).

T.C. Gelir İdaresi Başkanlığı (2000. 11 Mart), "410 Seri No'lu Tahsilat Genel Tebliği”, R.G. http://www.gib.gov.tr/gibmevzuat, (Erişim: 22.06.2017).

T.C. Gelir İdaresi Başkanlığı (2006), "Mükellef Hakları Bildirgesi”, http://www.gib.gov.tr/mukellef-hizmetleri/mukellefhaklari, (Erişim: 14.07.2017).

T.C. Gelir İdaresi Başkanlığı (2010), "Vatandaşlara Tanınan Haklar ile Başvuruda Bulunulabilecek Merciler", http://www.gib.gov.tr/mukellef-hizmetleri/vatandasataninan-haklar-ile-basvuruda-bulunabilecek-merciler, (Erişim: 14.07.2017).

T.C. Gelir İdaresi Başkanlığı (2012. 8 Eylül), “418 Sıra No’lu Vergi Usul Kanunu Genel Tebliği”, R.G. http://www.gib.gov.tr/node/88729, (Erişim: 11.07.2017).

T.C. Gelir İdaresi Başkanlığı (2014), Mükelleflerin Hakları ve Ödevleri Rehberi, Ankara: Gelir İdaresi Başkanlığı, Mükellef Hizmetleri Daire Başkanlığı, Yayın No: 185.

T.C. Gelir İdaresi Başkanlığı Büyük Mükellefler Vergi Dairesi Başkanlığı (2016), "2015 Faaliyet Raporu", http://www.bmvdb.gov.tr/dosyalar/bmvdb_2015_faaliyet_raporu.pdf, (Erişim: 14.07.2017).

Tekbaş, Abdullah; Hayrullahoğlu, Betül (2018), "Vergi Uyuşmazlıkları Bakımından Makul Sürede Yargılanma Hakkı”, Maliye Dergisi, S. 175: 253-274.

Tosuner, Mehmet; Arıkan Zeynep (2003), “Re'sen Vergilendirme ve Sorunlar”, Vergi Sorunları, S. 177: 63-77.

Tosuner, Mehmet, Arıkan, Zeynep (2011), Vergi Uyuşmazlıklarının Idari Aşamada Çözümü ve Türk Vergi Yargısı, İzmir: Kanyılmaz Matbaası.

Töralp, Funda (2012), "Temel Hak ve Özgürlüklerin Vergilendirme Yetkisinin Kullanımına Etkisi”, (Ed. Feridun Yenisey; Gülsen Güneş; Z. Ertunç Şirin), Anayasadan Mali ve Vergisel Beklentiler, İstanbul: On İki Levha Yayıncılık: 163-182.

Türkmen, Nedim (2016. 20 Haziran), “Amaç Tahsilat mı Iflas Ettirmek mi?”, Sözcü, http://www.sozcu.com.tr/2016/yazarlar/nedim-turkmen/amac-tahsilat-mi-iflasettirmek-mi-1282152/, (Erişim: 11.07.2017).

Üstün, Ümit Süleyman (2007), Türk Vergi Hukukunda Idarenin Takdir Yetkisi, Ankara: Turhan Kitabevi.

World Bank Group \& PWC (2017), “Paying Taxes 2017”, https://www.pwc.com.tr/tr/tax/yayin/ar/pdf/vergi-odemeleri2017-pwc-paying-taxes.pdf, (Erişim: 11.07.2017).

Yaraşır, Sevinç (2013), "Vergi Afları ve Türkiye'deki Vergi Aflarının Değerlendirilmesi”, Vergi Dünyası, S. 379: 175-187. 


\section{Extended Summary}

\section{Problems Due to Exceed the Boundaries of Using Tax Collecting Power of Tax Administration in Turkey}

Taxation is one of the most important powers of state. When the taxes, that levy based on state's taxation power, are not paid voluntarily by taxpayers, the collecting of them by compulsory becomes inevitable. For the purpose of forcible collection of public receivables, the tax administration has been authorised with the tax collecting power in Turkey. At that point, the tax administration can collect public receivables as independent of the provisions of private law by its own organisations and resorting distrain and in a similar way. In the process of exercising this authority, it may see that some illegalities are caused by tax administration occasionally. Because of not only the taxpayers and the tax jurisdiction, but also the tax administration are affected negatively by these illegalities, it is believed that exercising of power within the constitutional and legal boundaries has a great importance. In this context, the answer to the question whether the tax authority exceed the legal boundaries of using the tax collecting power in Turkey is sought in this study. Starting out the question of whether the tax authority exceed the legal boundaries of using the tax collecting power in Turkey, the study aims to reveal the boundaries of tax collecting power and consequences of exceeded the boundaries of the power for tax payers, tax authority and the judicial bodies.

Firstly, the boundaries of tax collecting power were determined in this study. The first boundary is defined as the limits on constitutional principles. Because the exercise of the tax collection power implies an interference with the constitutional rights of individuals. The second limit of the exercise of power is based on the limits of administrative acts. Because each act performed in the exercise of collection power is an administrative act. As the third limit, the cases which are stated in the law and which terminate the use of power or postpone it for a certain period are considered. Because the occurrence of these situations restricts the use of power completely or temporarily. The parties of the tax acts are the tax administration and taxpayers. Therefore, the consequences of exceeding the boundaries are explained for the tax administration and taxpayers. However, since the disputes between these two parties is solved in jurisdiction, the results are also evaluated in terms of the judicial bodies.

It is determined by the judicial decisions that the tax administration sometimes exceeds the boundaries in the use of tax collecting power. Explaining the points where the boundaries are exceeded is of great importance in determining the source of the problem and making recommendations to the administration. However, to explain at which points the boundaries are exceeded is beyond the scope of this study. This study mainly focuses on the problems due to exceed the boundaries of using tax collecting power of tax administration in Turkey. For this reason, document analysis method was used to determine the boundaries and results. In addition, the numbers of cases were analyzed in order to reveal the extent to which the judicial bodies were affected due to the exceed the legal boundaries of using the tax collecting power of tax authority.

As a result of reviews it is seen that, due to the unlawful acts of tax administration, besides the property rights of the taxpayers, some other rights such as human dignity, protection of personality and freedoms, protection of private life and freedom of communication, freedom to seek rights, protection of family and the right to work violated occasionally. As for the administration some unintended consequences occurred, such as decrease in tax revenues due to the slowdown in taxpayers' economic activities, delays in the transfer of receivables to the Treasury as a result of bringing the disputes to the judiciary, and trying to eliminate the income need caused by this situation by borrowing or amnesty laws. Due to the increase in the possibility and consciousness of individuals to carry arbitrary treatments of the administration to the judiciary, the increase in the workload of the administrative judiciary in which tax disputes are resolved affected the judicial bodies negatively.

In conclusion, as like in every other power, there are also some limits in the exercise of the tax collecting power. Article 13 of the Constitution draws the limits of limiting individuals' fundamental rights and freedoms. In this context, it is important to exercise the tax collecting power in the ways and extent determined in the law. The use of the power in the ways specified in the law is only possible if it is used in accordance with the rules applicable to administrative acts. Because each act performed in the exercise of collection power is an administrative act. Likewise in order to mention that the power is used in the ways specified in the law, it is also necessary not to continue the compulsory collecting processes in the event of some situations that delay or terminate the exercise of the power. 